\title{
Changes in Livelihood and Caste Relations in Udipur
}

\section{Madhusudan SUBEDI}

\section{Abstract}

There have been changes in the economic and social relations in Nepal. The market has been providing opportunities for choosing livelihood options. Livelihood diversification, particularly non-farm, appears to be growing in extent and importance in recent years. Although local wage labor has increased in farm sector, agriculture is not a path out of poverty. The relationship between caste and hereditary occupations has been less significant and there has occurred a significant shift in the bases of power. There is an increase in class consciousness and a decrease in caste consciousness; wealth is replacing birth as the basis of social power and prestige.

Keywords: livelihood diversification, power relations, Jajmani system, social transformation

\section{Introduction}

This paper presents caste relations and social transformation. It has focused principally to examine the livelihood change and its impact in caste relations in rural area which I call 'Udipur' located in a hilly district. I argue that changes in means of living and occupational diversification have contributed to shift caste-based relations. I had been in Udipur as a high school teacher for one and half years during 1986-87. The place was revisited in 2012-13. A caste does not exist itself. According to Leach (1960:5), 'a caste can only be recognized in contrast to the other caste with which its members are closely involved in a network of economic, political and ritual relationships'. Deshpande (2011) argues that caste-based occupational structure has undergone a profound change and the link between caste and occupation is broken. I have taken caste as a social phenomenon and social change as a process. In the first part of the paper, I will introduce the village of Udipur and the methodology followed. The livelihood change and its relationship with power, politics, class, citizenship and social transformation are discussed in other sections.

\section{Methods and Materials}

The information was collected through a phased and iterative data

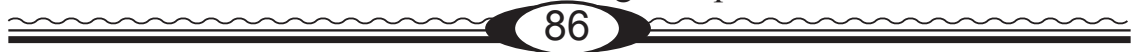


collection process (Mishra 2012). The first phase of visit was to test field methodologies and ensure the data to be collected in Udipur. The second phase was mainly focused on household selection and survey, and collection of qualitative data from different sources and methods. A range of households were selected to represent different social and economic groups, female headed households, households with less diversified and more diversified, migrant and non migrant households. Through semistructured interviews and focus group discussions at the village level, the field research attempted to develop a composite picture of drivers and nature of change. Filed work was conducted in October-November 2012, January-February 2013. Head of the households, youths, school teachers and mother were interviewed either individually or in small focus groups. Wide ranges of people were met from different socio-economic, caste, ethnicity, gender and class backgrounds. Interviews and interactions were conducted outside the house, in school, in VDC Office, or in the field. Conversations were allowed to develop organically starting from very general questions such as what has changed in the village in your life in the last 20-25 years. A rapid assessment was made in each settlement of households to establish how caste-based relation has changed over 25 years and the reasons for change or remaining the same.

\section{The Village}

The village, Udipur, lies in Pyuthan district which is about one and half hours walk from the local market. There were 260 households in the study village comprising of mainly Brahmins, Dalits and Magars. There are six settlements among which, five have settlement history of more than 250 years. In the past, people were living closely with the members of same castes. It was general rule for members of different castes to live in different sections of the village. Better houses were usually located at the centre of the village while the others were constructed in peripheral areas, at a slight distance from it. It was not difficult to distinguish two residential areas at least at first glance-the group of households occupied by non-Dalits and Dalits. These residential areas were denoted by the word tole, to which the name of the caste is prefixed. Bahun tole, Magar tole, Kami tole, Damai tole, Sarki tole are some of the common caste prefixed tole in Udipur. The Brahmins were the land-owning caste, while the Kami, Damai and Sarki were the poorest section of the landless inhabitants.

In the past, people in Udipur used to divide caste into three strata-the 
upper stratum containing the Brahmin and Chhetri, the middle stratum containing the Magars, and the lower stratum containing the Kami, Damai and Sarki. It can be said that representatives of the upper stratum in the villages were land-owning class while the lower stratum was composed of landless laborers and tenant peasants. The middle stratum may be regarded as having lived in a state of economic as well as social dependence on the caste in the upper stratum. The more the khet land one had, the higher the social and economic status of the household and family would be.

In the past, land was the main basis of livelihood, and those who controlled it, primarily the Brahmins and Chhetris, used to control the economy. Ownership of land, and especially of irrigated land, was highly correlated with wealth. The Dalits, on the other hand, had to work for wealthy household as agriculture wage laborers. Currently, although there is variation in wealth and landownership by household and by caste, there are no big landholders in the sense of 'zamindars' of the Tarai. None of the household is recorded as landless. Most of the households are ownercultivators; they live by their own work and land.

One of the significant changes identified by the villagers was the general decline of forms of unremunerated labor in agriculture. In the past, if one had no piece of land to work on, one would have to ask someone who had more land to give a piece of land to sharecrop for survival. The land was given in return for specific number of days unremunerated labor on owner's field. One should also provide labor services to help task of landowners. These were the poor households and the members of these households had relatively weak social relationship and information networks.

Agriculture in Udipur is a family enterprise. Rice, maize, wheat, barley and millet are the main staple crops which govern the work of villagers and influence the yearly cycle of all activities in Udipur. Other crops include beans, ginger, chili, cucumber, tomato, cabbage, cauliflower, leafy vegetables and potato. The nature and extent of cultivation of some crops is limited by the type of land available. Agricultural productivity has not changed perceptibly, and aside from an increase in vegetable growing of some households for consumption and sale, the entire agricultural scene has not been changed that much. People prefer and use compost fertilizer. Practice of using chemical fertilizers has slightly increased but they have the perception that chemical fertilizers damage soil and its fertility, and taste of the crop also become substandard. The practice of the use of insecticide is very low. 
Growing cash crops primarily for sale is a relatively recent improvement in the village. There is a demand for fresh vegetables in the local market center, a few farming household had begun to experiment with vegetables (cauliflower, tomato, modern hybrid beans, modern cucumber etc.) in their fields. There was a general move towards growing cash crops (including green vegetable to sell nearby markets). Agricultural programs introduced by the state in partnership with aid agencies and NGOs had led to transformation in agricultural practices.

Closely related to agriculture is animal husbandry. The purpose of domesticating animals is mainly for subsistence. Both agriculture and animal husbandry are open to and practiced by all caste/ethnic groups. Buffalo, cow, oxen, goats and chicken are important animals in the village. Buffalos and cows are kept for their two valuable products, milk and manure. Animal manure is considered necessary for agriculture and is often sufficient reason for keeping such animals. In the past, the cows, oxen and goats were grazed in the forest during the day time. Currently, almost each ward has community forests, and grazing in the community forest is prohibited. In such situation, almost all households started to reduce the number of cows to be domesticated. Only few households have one or two cows, domesticated either for milk or ritual purpose. The family, which cannot afford to buy buffalo for milk purpose domesticates cows. Secondly, since they do not graze the buffalo and cows in public land or forests, the lesser number of livestocks would be enough for compost manure. The migrant households have smaller number of livestock due to lack of labor available to look after them. Each household has at least some fodder trees of their own for their cattle in the bari land or in kharbari. Compared to past, there is increase in fallow land, and an increase in trees on the private land. The number of domesticated goats has been increased and the purpose of domestication is subsistence and sale.

\section{Discussions}

\section{Changing Livelihoods}

Livelihood incorporates the diverse ways in which people make a living and build their worlds (Whitehead 2002). The motives for diversification may vary. Diversification is the survival for the poor, away from poverty for those who are on an upward path, and for the rich accumulation of income and assets. Thus, livelihood diversification is a phenomenon that characterizes survival and income strategies in individuals and 
households. Livelihood diversification has increased over time. There are many reasons for this, amongst which changing incentives and labor markets, risk strategies, impact of disasters and civil strife, saving and invest behavior, all contribute differently in different settings (Ellis 1998). It is differentiated in its causes and effects by location, demography, vulnerability, income level, education and many other factors. Thus, livelihood study emphasizes the importance of local contexts and circumstances. This is also true that the analysis of rural livelihood is cast within the specific context of the larger political-economic system and focuses on understanding on how macro forces both influence and are influenced by what happens at the local level (Hart 1986). The pattern of social relationships and livelihood strategies of different households is part of a larger process of structural change.

Scholars like Blaikie et al. (1980) Mishra (1987, 2007), Adhikari (2008) and Adhikari and Hobley (2013) have highlighted Nepal's integration with global system. Many have focused new remittance economy and livelihood change, the mobility of the people from rural to urban areas, the flow of good and commodities, and flow of information and communication. Various reports of the Nepal Living Standard Surveys conducted in 1995, 2003 and 2010 have shown that wage rates in the agricultural sector have increased (CBS 1996, 2004 and 2011). The traditional caste-based relationship becoming weak and the new relationships are developed in rural areas. In the following paragraph, I have focused changing livelihood and its impact on caste relations in Udipur.

In the past, a number of activities in the village, especially those requiring particular skills or knowledge, were performed by the specific caste groups in Udipur. Most of these occupations were thought of as caste specific, and the arrangement for work and payment were standardized in some form of traditional exchange, the jajmani system. Such system was very common in India and Nepal (Berreman 1972, Cameron 1998). The economic base of the village was based on ownership of land and certain social relationships were established among various castes. The Brahmins and Magars were primarily agriculturalists. Very few Brahmins were engaged in priestly work. An artisan or service caste members were responsible to provide services. They were paid a fixed portion of grain at each harvest. The amount depended upon the size of the household or landholding of the agriculturalist and the type of the service performed. Ideally the relationship was permanent one with standard traditional payments, but 
in practice a good deal of shifting was always possible where there were more than one local artisan available. The traditional economic exchange was not only between high caste and artisans but also among the artisans. Blacksmiths, for example, had to get service from the tailors and vice versa. In the past, Jajmani system was very common in Udipur. The common term used for such system is balighare ${ }^{l}$. The term bali literally means cereal crop. It also refers to annual wages paid in kind by farming households to people to employ (Dalit or other castes depending on the nature of service needed and the speciality of the service providing caste in question) during an agricultural year to perform various kinds of tasks including plowing, making and repairing farming equipments, sewing and mending of clothes/garments etc.

Under the bali system in Udipur, Dalits were paid an annual wage in kind at the time of the harvest of the major crops. The amount paid varies by type and extent of services provided or received. The rate for different types of services is fixed by customs varying sometime according to the place and occupation. Such practices are also common in other parts of Nepal (Blaikie et al., 1980, Shrestha 1993, Cameron 1998, Pokharel and Chhetri 2006). However, every farming household paid small shares from their annual grain production to Dalits who provide their caste-based services irrespective of annual variations of demand of such services. The local Damai provided tailoring services to all other castes and received bali from their clients. The Kamis provided maintenance services - most important of which was sharing of agricultural instruments and kitchen utensils to their client households. The Sarki of Udipur manufactured nara, a strap of tanned leather which is used in joining the haris and juwa (yoke) of a plough together.

The Jajmani system was not operated according to the principle of an exchange of equal values, but took the form of services performed by the members of Dalits (Kami, Damai and Sarki) for the benefit of the dominant castes, the Brahmans, Chhetris and Magars. They used to give the Dalits an assured livelihood by means of payment in kind. For this reasons, the payment in kind made to Dalits depends on the patron. The caste system associated in these ways with certain traditional hereditary occupations was maintained by the economic power of the land owners, that is, by the 
agricultural producers. Agriculture was the occupation of almost all castes but was the main occupation of the dominant. These dominant castes were the ruler power in the economy of the villages. In these circumstances, agricultural production was never organized as a means of acquiring profit by reinvestment in the expansion of the scale of reproduction, but had the function of maintaining the traditional mode of living in the village.

The Jajmani system underwent gradual changes in Udipur, in particular after 1950. Economic development of the country led to the penetration of monetary economy into the village and villagers came to regard a certain level of monetary income as a necessity to be used for purchasing market products. Further, modern industrial production started to have some effects on the traditional occupational structure in the village. The hereditary occupations associated with the caste system became incapable of maintaining themselves, and even where the traditional occupational system was not brought to complete dissolution, many of the traditional occupations came to require fewer workers than in former times. Currently, many similar services are still performed in Udipur but on a piece work or daily wage basis with cash or grain used for payment. When this happened, the annual payments in kind which were intended to assure the livelihood of the Dalits under the jajmani system changed their nature. Patron of the past lost their power from land.

Apart from their engagement in managing their farms, the most obvious source of income for poorer household is seasonal migration to India and daily wage labor. This is much more important in terms of the number households involved and scale of remittance in the seasonal migration of labor to India (Mishra 2007, Seddon 2013, Adhikari and Hobley 2013). Migration to work in Indian cities (Delhi, Mumbai, Bangalore, and Punjab) is a popular practice among men in villages. Working in India or outside the villages is considered better than working as an agricultural laborer in the village. Migration to Indian cities enabled men to remit money to support their households and occasionally provided them with opportunities for consumption of goods and experiences. It is likely that remittance flows in the villages have functioned as a safety net for households of migrants and helped to cope with the rising food prices. A few women have gone with their husbands or relatives to find work in India. Throughout the fieldwork areas, migration to market centers like Ghorahi, Lamahi and Tulsipur of Dang district, Nepalganj and Kohalpur of Banke district and to Kathmandu Valley was found to be common to some economically better 
households who had the educational qualifications and social networks to look for jobs in the cities. In the last 25 years, increasing numbers of males with educational qualifications of Bachelor or above have migrated to the nearby towns and cities like Kathmandu in search of job opportunities. Thus, occupational multiplicity is becoming more common and more pronounced and the balance of household income is shifting from farm to non-farm. Livelihood and poverty are becoming delinked from land and from farming. Remittance is playing a growing role in the rural household income. Lives are becoming more mobile and livelihoods correspondingly delocalized. The non-farm activity becoming central to the rural livelihoods and an increasing number of rural households have no commitment to farming. It is, therefore, more pronounced transition from one way of making a living to another. No longer is access to land, a necessary condition for reducing poverty, and farming has simply become one of the activities among many in Udipur. A larger number of households receive remittances from their family members working in different locations within and outside Nepal.

A very visible change can be seen in the economic condition of some migrant Dalits households. Some households have built new houses with zinc or slate roofing. This is a huge change compared to their housing with thatched roofing prior to migration. Others have repaired their houses to give them new looks. Similarly, before migration the household members used to dress in ragged clothes, and they used cloths donated by their bista (usually upper-caste people) but now they no longer accept used clothes from their bista.

In the past, caste had a significant role in shaping occupations and roles as well as values of various activities in Udipur. Hereditary occupation was an expected role of the household members. The situation has changed. Relationships between castes have become more relaxed today. There is more food sharing between castes and a lot more eating done at local restaurants where caste distinctions are less likely to be made. One of the biggest changes that took place in Udipur is occupational pursuits of various castes. Many have now taken up newer occupations that do not relate to their caste, such as government jobs, teaching, retail and services, and repair work. Wealth and power in the village is now less associated with caste than before.

\section{Power and Politics}

In the past, decisions were taken by the leaders of the dominant castes, 
and a compromise agreement was regarded as the unanimous decision of the whole meeting. It was difficult for any of the members to resist such decisions. But now the voting procedures has been adopted which has become possible for members to express their opposition. At the same time, the connection between the political leaders and external political power has been strengthened under the multi-party political system. The Dalits feel that there has been change in power relationship in the village. The Dalits have been raising their concerns on caste-based oppression and discrimination issues. They have been able to argue with 'high' caste people.

In the past, politics was regarded as the sole preserve of the non-Dalits. The current situation is different. People belonging to all caste/ethnic groups are becoming conscious that they can play an important role in the political processes and can be benefitted from them. Political events in the village after the establishment of multi-party system have given the Dalits and Magars a strong feeling of empowerment. Power has become independent of caste to a greater extent than in the past.

Outside contact has resulted in greater awareness of the outside world in the village than was previously. The youths, mainly the males go to town more often, they know better how to deal with officials, and they are less vulnerable to both officials and business persons. People are better informed on the events outside the village and its vicinity than before. They are, in short, more active and capable participants in the larger society. The experiences of urban life have helped many non-Dalit youths to challenge their own beliefs and traditional discourse and practice along caste lines. Such acts have been contributing to shift the power game in Udipur. The social changes which have been taking place in the village are the products of wider socio-economic and political changes in national and international contexts.

\section{Caste, Class and Power}

One of the serous limitations of the studies of social stratification is that caste has been considered as a logical opposite of the class system. Sharma (1994) argues that, at no point of time caste system was a 'closed' system, and class was so not 'open' system even in the western world. There are number of points which have so far remained unclarified in regard to the nature of caste and class in Nepal. The day-to-day life of the people and their interaction among various caste groups clearly show a long history of discontinuities, breakdowns, contradictions and changes in the caste 
system which negates its absolutists, unchanging and holistic nature. Caste has acquired a new form, and it has also changed to a great extent as a system of social relations (Subedi 2010). The emergence of a new middle class disproportionate to the forces of production and the size of the upper and lower classes had forged a new nexus between caste, class and power. Highlighting the structural shift of Nepal, Kharel (2010:113) writes;

Today Nepal is undergoing a deep structural shift: away from predetermined and largely unchanging caste/ethnic identity as the primary basis for social status and economic and political power, towards a more open, class-structured society where status is based on attributes like education, wealth and political influence which (at least theoretically) can be attained through individual effort.

The number of large landowners in Udipur has gone down due to share of inheritance by the son which has greatly reduced the size of individual or family holdings. The landowners very often have to support one or more children studying outside. This makes them difficult to meet cost of living and education of their children in urban areas. The easiest way to manage the cost is to sell the land in the village. At the same time, the children who received higher education from Dang, Nepalganj or Kathmandu did not want to comeback to village and engage in agricultural work. They gave pressure to the parents to sell portion of land in the village to buy housing land (ghaderi) in the market centers. Thus, a section of the family members of the landowners left the village and settled in market centers. At the same time, those family members who live in the village not only sold the land in village but also lost their control over affairs in the village. One clearly sees in the village that the current leaders in the village are not the members of the old landowning class; they generally belong to small owner cultivator. There is certain divergence between political and economic power in the village. The relatively big landowners in the village are no longer the ones who were politically the most powerful in the past. With the growth of education in towns, new ideas and moral values spread gradually to the rural areas. Dalits have given up the flaying of dead cattle and other such degrading tasks allotted to them by the traditional division of labor in the village economy. They now depend for their earning mostly on wage labor. The positive side of the picture is the increasing consciousness about civil and political rights among the Dalits. The educated Dalits are now competing with the Non-Dalits for administrative 
posts and other jobs in private sector. Thus, production is freed from jatibased division of labor, economic relations are becoming autonomous and the grain payments are replaced by the cash.

There has been a sharp decline in the supremacy of the Brahmins in Udipur. In the past, the Brahmin occupied the topmost position in the caste hierarchy. But today the Brahmins do not enjoy the same social status which they once used to. Certain factors such as occupational diversification, migration to urban areas, role of media and state have helped to break the boundaries between caste groups. The expansion of communication helped to the creation of a new culture based on information and observation rather than faith and rumor (Mishra 2007). There is an increasing degree of interpenetration between different groups, classes and categories. A gradual lessening of the congruence between caste, class and power is visible. Thus, the relationship between caste and class is not completely straightforward, a tentative pictures of congruence between the two does indeed appear. High castes are seen to be concentrated in the higher social classes like the professional class, and large business and farming classes. But, significantly, we observe that they are also concentrated in the two routine non-manual classes.

\section{Caste and Citizenship}

Caste discrimination was considered a major issue by Dalits. Dalits, throughout the study areas felt that they were facing discrimination from the state as well as from the local high caste people. Dalits and non-Dalits stated that discrimination has substantially decreased over the last 20-25 years and there was a greater acknowledgement of this issue. Traditional patron-client relationship had decreased in all areas and other research findings also show the similar situation in other parts of $\mathrm{Nepal}^{2}$. Dalits felt that caste discrimination was still the most important issue for them, whereas many non-Dalits felt that things has changed in the last 20-25 years and people no longer discriminated on the basis of caste in public sphere.

There has been a major change in terms of material aspects of labor relations with a clear shift from caste-based or other forms of attached labor to cash-based wage labor both within and outside agriculture, but also in the more symbolic aspects of labor relations in terms of the awareness of the laborers' identity as citizens with rights (Sharma and Donini 2010). Most of the Dalit respondents who were engaged in caste-based attached labor mentioned that such relationship was exploitative. They 
were engaged in either sharecropping practices or agricultural wage laborers as they did not have sufficient land for farming. Some households had practiced half sharing of cattle such as buffalo, cow and goats. The most common caste-based labor system in Udipur provided were home service of iron work and tailoring from which ther would receive a fixed amount of grain (bali) in return annually. These occupational castes had to demonstrate their loyalty by providing services and receive their share of grain. During festivals and significant family occasions, those who provide services were given more grain, and sometime already used cloth $^{3}$ or money for their additional work. This would happen during the weeding of the family members of the clients or a special worship like a full week worship of the god and goddesses (saptaha).

The poor Dalit and Magar respondents mentioned that they had spent their adulthood as a hali, an agricultural form of labor. They had worked as their father had taken some of money as a loan but could not return them on time. As a way of paying interest they had to work more than 30 days in a year. The interest rate was very high and it was difficult to pay this liability by their father, and was passed on to them. Traditionally, the local power holders especially those who owned more land, had control over the poorer households, especially the Dalit households. Many Dalits had to work as hali for the non-Dalits, and had to work free of cost.

But situations have reasonably changed. Currently, labor in agricultural or non-agricultural work receive wage (jyala) in cash or grain. Working hours are specified, and so are the rates. This can be done in any kind of labor such as tilling the field, digging, planting of seeds, weeding, harvesting of crops, and construction of house, work in irrigation cannel or work as a porter. This is referred as jyaladari system.

Mishra (2007:30) argues that the expansion of education, among others, led to an increasing popular demand for the creation of an individual-centered and achievement-centered resource endowment that contributed the enhancement of productivity. It also tended to insistently question the legitimacy of the "traditional" order, including the traditional political order, right from the household level to the national.

Increasing opportunities for wage labor both within and outside of the village had opened up significant opportunities to transcend attached labor system. It offered a major potential for transformation of economic and social position of the laboring households. Many of the changes in labor relations and labor practices have had significant positive effects on poorer 
households, in terms of their rights and increased opportunities. People have become aware and without any fear can speak for their rights and existence. Earlier, Dalits hardly could participate in any sort of gathering but now they have been participating in different programs and have become much more assertive than before. However, these opportunities have not been equally accessible to all. Some are still trapped in their traditional forms of labor relations whereas others have their livelihoods by migrating for work.

There have also been various groups and committees established in the area that have been advocating for the rights of the poor. The Dalits have gradually turned from being subjects of landlords and non-Dalits to citizen of the state, and are more able to articulate their demands and their rights (Sharma and Donini 2012). There are, however, disparities on the benefits that have been provided by the opportunity of migration for work, non-agricultural wage labor, employment in the informal sector services. Those who are too old, weak or ill or lack marketable skills face greater vulnerabilities than before. Similarly, some of the Brahmin households are finding it difficult to transit to a situation where the rights of citizens clash with their perception of their past inherited authority.

\section{Conclusion}

Nepal is going through a transformative process in which many existing social norms and patterns are being challenged and many are being reformed. The rural areas are not isolated from information and ideology as a result of road construction, migration, remittance and penetration of media and telecommunication. Such global processes are undoubtedly affecting the lives of rural families in important ways. Education is no more confined to the higher castes. People in the rural areas are aware of their rights and have given emphasis in education. There is evidence of changes in caste, gender and power relations at varying degrees at local levels. The most important change can be seen in the caste domain, where there has been significant reduction in discriminatory practices, more evident in public than private sphere. Such situation has created changes in power relations. Every household, despite of their caste/ethnic background, have been struggling to engage in diverse economic activities for survival and in order to improve their living standard. The migrant households and Dalits have improved their socio-economic condition in the community. The Dalits have started to run business in the village. Women's collective 
agency has equally increased. There has been a greater shift from a castebased ascribed status system to an achieved one and the individual's distinctive qualities and attainments are linked to social status.

In the changing social scenario, birth no longer constitutes the basis of social prestige. Criteria such as wealth, ability, education, efficiency etc. have become the determinants of social status. Occupation is not the hereditary monopoly of any caste any more. One is free to take up any occupation he likes according to his/her ability and interest. The pattern of intercaste relations has undergone profound changes. The mutual rights and obligations characterizing inter-caste relations have crumbled down. The Dalits no longer obey the orders of the members of Brahmins and Chhetris. They do not come forward to perform forced labor for the members of the non-Dalits. A growing remittance economy enabling alternative sources of livelihoods has allowed members of the Dalit community to challenge their place in the social hierarchy. A number of legal documents, such as the 1991 Constitution, the 2007 Interim Constitution and the Caste Based Discrimination and Untouchability (Offence and Punishment) Act 2011 grant Dalits equal access to public spaces.

There has been a major change in the representation of and participation in the social sphere. There is change in class relation, though not remarkable. In the past, land was greatly loved and valued. Non-farm regular income has been more valued. Diversified livelihood options along with the transportation and communication and education facilities have been influential in bringing about change. People often use the term samajik pariwartan (social change) to talk about the changes and transformation seen in their communities. There is a divergence is power relationships in the village. In the past, political power was in the hands of Brahmans with the exception of the Magars. The current situation has been different, power is neither directly related to the caste hierarchy nor to economic hierarchy but has been a complex phenomenon. Those who are powerful in the village can not accurately be described as big landholders. This does not mean, however, that the political power has gone into the hands of landless or poor Dalits, these groups are still largely in a state of subordination. Candidate's personal influence and support of the political party, network of individual to district, regional and, with direct link to central level leaders, and social capital of the individual play strategic role to acquire political power in the village and surroundings. Political power can be achieved and shifted easily to the common people than was the 
case in the past. Opportunities and authorities have been shared among the Brahmans, Magars and Dalits by making different political, social and economic organizations caste/ethnic inclusive.

\section{Endnotes}

${ }^{1}$ This system is known as Riti Bhagya system in western Nepal as popularized by Mary Cameron in her book, "On the Edge of the Auspicious: Gender and Caste in Nepal." Through this system, they were just able to sustain subsistence living while facing castebased discrimination.

${ }^{2}$ In a village in Palpa, Dalits had abandoned the balighare system (providing various services including tailoring, iron work, etc. on bonded contract), which was considered exploitative. Similarly, the haliya (ploughing on a bonded contract) system was abandoned in Doti and Dadeldhura districts on the same grounds (Sharma and Donini 2010).

${ }^{3}$ During the fieldwork, some of the old respondents mentioned that the rich patrons used to give already used but still usable clothes like Daura, Suruwal, Coat to the ironsmith or tailor or for their family members. Choli, Dhoti or Sari, petticoat were the other cloths to be given to the females of the clients.

\section{References}

Adhikari, Jagannath (2008). Changing livelihoods: Essay on nepal's development since 1990. Kathmandu: Martin Chautari.

Adhikari, Jagannath and Mary Hobley (2013). Everyone is leaving - who will sow our fields? The effects of migration from Khotang district to the Gulf and Malaysia.

Kathmandu: Nepal Institute of Development Studies.

Berreman, Gerald D. (1972). Hindus of the Himalayas: Ethnography and change. Berkeley: University of California Press.

Blaikie, Piers, John Cameron and David Seddon (1980). Nepal in crisis: growth and stagnation at the periphery. Delhi: Oxford University Press.

Cameron, Mary M. (1998). On the edge of the auspicious: Gender and caste in Nepal. Urbana, IL: University of Illinois Press.

CBS. (1996). Nepal living standards survey report 1995-1996: Main findings. Kathmandu, Nepal: Central Bureau of Statistics.

CBS. (2004). Nepal living standards survey, 2003-04: Statistical report.

Kathmandu, Nepal: Central Bureau of Statistics.

CBS. (2011). Nepal living standards survey, 2010-1: Statistical report. Kathmandu, Nepal: Central Bureau of Statistics. Deshpande, Ashwini (2011). Grammar of caste: Economic discrimination 
in contemporary India. Delhi: Oxford University Press.

Ellis, Frank (1998). Household strategies and rural livelihood diversification. The Journal of Development Studies, 35(1):1-38.

Hart, Gillian (1986). Power, labor and livelihood: Processes of change in rural Java. Berkeley: University of California Press.

Kharel, Sambriddhi (2010). The struggle for full citizenship for Dalits in Nepal: Approaches and strategies of Dalit activists. In Arjun Guneratne (ed.) Dalits of Nepal: Towards dignity, citizenship and justice (108-144). Kathmandu, Nepal: Himal Books.

Leach, E.R. (1960). Introduction: what should we mean by caste?. In E.R. Leach (ed.) Aspects of caste in South India, Ceylon and North-West Pakistan. London: Cambridge University Press.

Mishra, Chaitanya (1987). Development and underdevelopment: A preliminary sociological perspective. Occasional Papers in Sociology and Anthropology, 1:105-135.

Mishra, Chaitanya (2007). Essays on sociology of Nepal. Kathmandu: Fine Prints.

Mishra, Chaitanya (2012). Discussion on the logic of research site selection. Kathmandu: Unpublished Memo.

Pandit, Nalini (1979).Caste and class in Maharashtra. Economic and Political Weekly, 14:425-436.

Pokharel, Sanjeev K. and Ram B. Chhetri (2006). Changing livelihood strategies of Dalits: A case study in the Pokhara valley. Contributions to Nepalese Studies, Special Issue 33:63-80.

Seddon, David (2013). Introduction. In Jagannath Adkikari and Mary Hobley. Everyone is leaving-who will sow our fields? The effects of migration from Khotang district to the Gulf and Malaysia (xii-xix). Kathmandu: Nepal Institute of Development Studies.

Sharma, Jivan Raj and Antonio Donini (2010). Towards a "Great transformation"? The Maoist insurgency and local perceptions of social transformation in Nepal. Medford: Feinstein International Center.

Sharma, Jivan Raj and Antonio Donini (2012). From subject to citizens? Labor, mobility and social transformation in rural Nepal. 
Medford: Feinstein International Center.

Sharma, K.L. (1994). Social stratification \& mobility. New Delhi: Rawat Publications.

Shrestha, Bihari K. (1993). A Himalayan enclave in transition: A study of Change in the western mountains of Nepal. Kathmandu: ICIMOD.

Subedi, Madhusudan (2010). Caste system: Theories and practices in Nepal. Himalayan Journal of Sociology \& Anthropology, 4:134-159.

Whitehead, Ann (2002). Tracking Livelihood Change: Theoretical, Methodological and Empirical Perspectives from North- East Ghana. Journal of Southern African Studies, 28 (3) 575-598.

\section{Acknowledgements}

This paper emerged from the research project 'Households, Livelihoods and Social and Political Transformation in Nepal'. I would like to thank Prof. Chaitanya Mishra for his guidance and encouragement to write this paper. 